\title{
A forja d'O Anel do Nibelungo: a contribuição da ciência*
}

\author{
João Paulo André \\ Departamento/Centro de Química, Universidade do Minho - Braga \\ jandre@quimica.uminho.pt
}

Forging the Ring of the Nibelung: the contribution of science - The scientific and industrial world at the time of Richard Wagner is traversed in four tableaux: gods and elements, the cursed metal, limits of science, endless melody. The impact it had on the conception of The Ring of the Nibelung is analyzed and the scientific contents of this tetralogy are discussed while a connection with the sciences of evolution is established.

A o longo de quatro quadros - deuses e elementos, o metal maldito, limites da ciência, melodia sem fim - percorre-se o mundo científico-industrial contemporâneo de Richard Wagner, analisando-se o seu impacto na produção d'O Anel do Nibelungo. Simultaneamente, discutem-se os conteúdos científicos desta tetralogia e estabelece-se uma ligação com as ciências da evolução.

\section{Deuses e elementos}

Poucos compositores e dramaturgos terão revelado tanta preocupação com a relação do Homem com a natureza como Richard Wagner (Figura 1). O período da sua vida, 1813-1883, coincidiu com uma época marcada pelos ecos das expedições científicas do geógrafo e naturalista Alexander von Humboldt, pelos achados geológicos de Charles Lyell que indiciavam que a Terra teria milhões de anos e que a Natureza era una, e pelas célebres expedições de Charles Darwin a bordo do lendário navio HMS Beagle, que originariam uma das maiores revoluções de sempre na ciência biológica (Figura 2).

A Tetralogia $O$ Anel do Nibelungo de Richard Wagner - onde se vislumbra o arco-íris, se escuta a água, os murmúrios da floresta e o canto dos pássaros - não deixa de espelhar essa contemporaneidade científica. Contudo, numa primeira instância poder-se-ia afirmar que a sua narrativa é dominada por uma visão aristotélica do Universo, pontuada pelos quatro elementos primordiais da Antiguidade (Figura 3).

Nos séculos VII e VI antes da era cristã, Heraclito de Éfeso considerou o fogo o princípio de todas as coisas; por

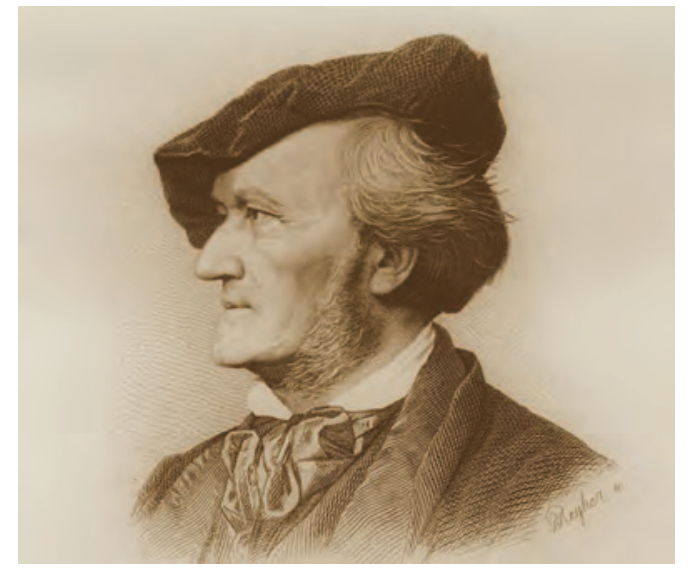

Figura 1 - Richard Wagner (1813-1883)

sua vez, Tales de Mileto defendeu que esse princípio era a água, enquanto que para Xenófanes de Cólofon era a terra e para Anaxímenes de Mileto o ar. Seriam esses princípios que Empédocles de Agrigento, no século V a.C., iria considerar como os quatro elementos primordiais da cosmogonia. No século seguinte, ao retomar o conceito de uma matéria primordial única, constituída pelos quatro elemen-
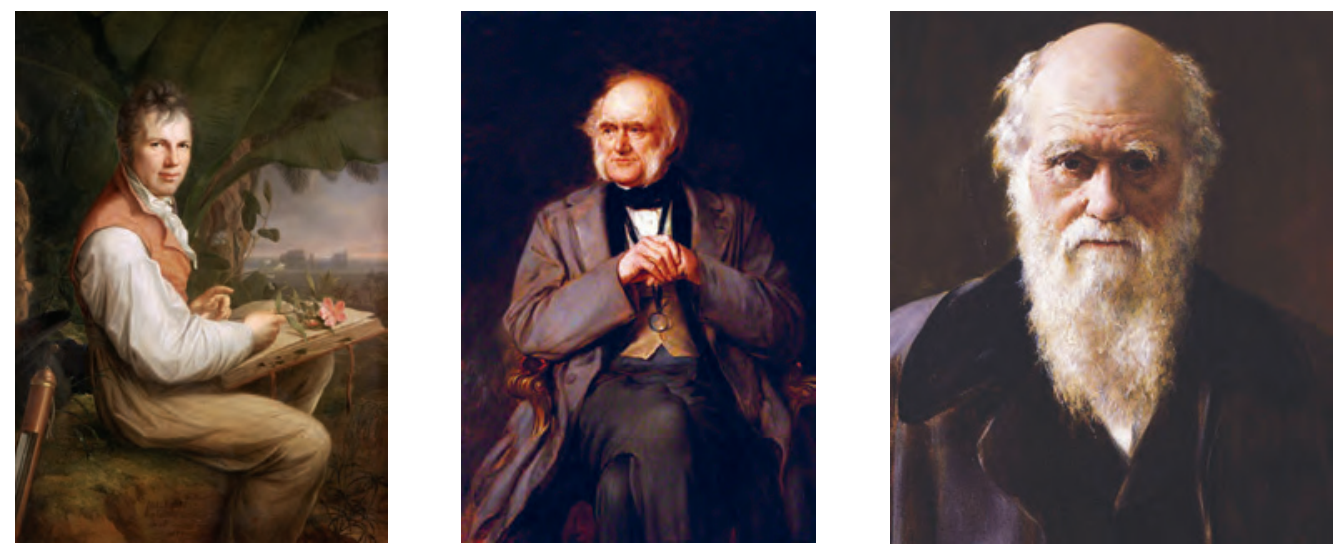

Figura 2 - Alexander von Humboldt (1769-1859), Charles Lyell (1797-1875) e Charles Darwin (1809-1882)

\footnotetext{
* Conferência proferida no Goethe Institut (Lisboa) a 16 de Novembro de 2016, integrada no ciclo "Mito e natureza humana: 4 visões sobre o Ring”, comemorativo dos 140 anos d'O Anel do Nibelungo de Richard Wagner.
} 

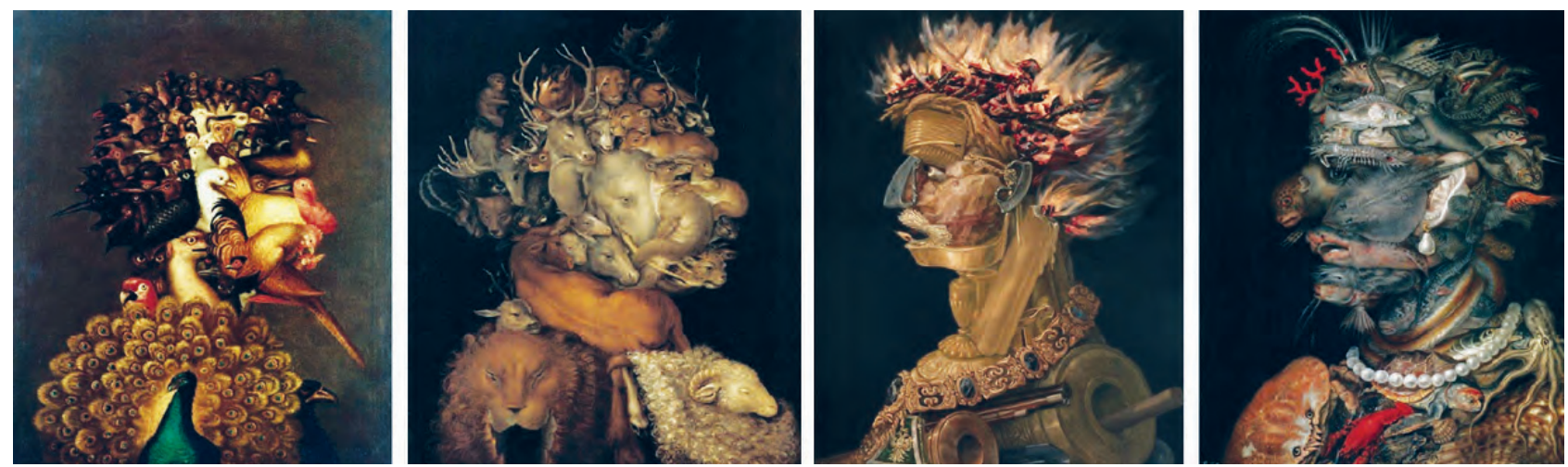

Figura 3 - Os quatro elementos aristotélicos segundo Giuseppe Arcimboldo (1566): ar, terra, fogo e água

tos combinados em proporções variáveis, Aristóteles defendeu que seria possível transformar as substâncias umas nas outras. Tal ideia faria com que, durante muito tempo, os alquimistas tentassem encontrar a quantidade certa de fogo que tinham de adicionar à terra dos metais vis para obterem ouro.

O Ouro do Reno, a primeira ópera da Tetralogia, começa sob o signo da água. Os primeiros quatro minutos de música (136 compassos em bi bemol maior, que é a tonalidade doce e heroica da natureza) são uma imagem musical de um fluxo aquático incessante em que se poderá ver a criação do mundo (e da vida). A última jornada da Tetralogia, Crepúsculo dos Deuses, termina nos antípodas: a destruição do mundo pelo fogo. A terra e o ar, como se verá, são igualmente convocados n'O Anel do Nibelungo. É a tetrassomia - a disciplina dos quatro elementos - ao serviço da Tetralogia wagneriana.

Não obstante, quando Crepúsculo dos Deuses estreou em Bayreuth, a 17 de Agosto de 1876, a conceção aristotélica do cosmos há muito que tinha sido descartada. Graças aos trabalhos de Henry Cavendish, James Watt e Antoine Lavoisier (Figura 4), há quase um século que o mais simples dos quatro elementos primordiais, a água, se sabia ser um composto de oxigénio e hidrogénio. Para além disso, Lavoisier também interpretara corretamente o fogo como o resultado de uma combinação de um "corpo combustível” com o oxigénio. Quanto ao ar, a química pneumática revelara tratar-se de uma mistura elástica formada maioritariamente por dois gases, o oxigénio e o nitrogénio. E da terra era possível obter os metais - os antigos e outros que entretanto se conheceram.
Como se não bastasse, à data da estreia d'O Ouro do Reno, em 1869, a moderna teoria atómica, iniciada em Inglaterra por John Dalton (Figura 5), já contava com seis décadas de existência. Por coincidência foi também nesse ano que o químico russo Dmitri Mendeleev (Figura 5) ordenou os elementos químicos segundo as suas propriedades, criando a Tabela Periódica - hoje considerada uma das grandes realizações do intelecto humano.

Estaria Richard Wagner a par dos grandes avanços da química das últimas oito décadas; isto é, desde que Lavoisier publicara em 1789 o seu Tratado Elementar de Química? Claramente! À sua vasta cultura clássica, o compositor somava um grande conhecimento da sociedade e dos progressos do seu tempo - os científicos incluídos.

Grande conhecedor das lendas germânicas e das mitologias, da greco-romana às do norte da Europa, não lhe foi difícil rever nos temas universais das narrativas mitológicas a decadência dos valores filosóficos, políticos, sociais e económicos de uma época - a sua - que, com voracidade, colhia os lucros da Revolução Industrial. O Anel é assim, a um tempo, uma alegoria de exaltação da vida (e, claro, do amor!), e de denúncia de uma sociedade dominada pela mecanização e pela ânsia de poder e de riqueza (rápida, de preferência). Tal como Bernard Shaw observou no seu O Perfeito Wagneriano: Um comentário sobre o Anel do Nibelungo (1898), “o Anel, com todos os seus deuses, gigantes e anões, as suas donzelas aquáticas e Valquírias, o elmo dos desejos, o anel mágico, a espada encantada e o tesouro miraculoso, é um drama de hoje e não de uma remota e lendária antiguidade. Nunca poderia ter sido escrito antes da segunda metade do século XIX, dado tratar de acontecimentos que só então se consumaram.’”
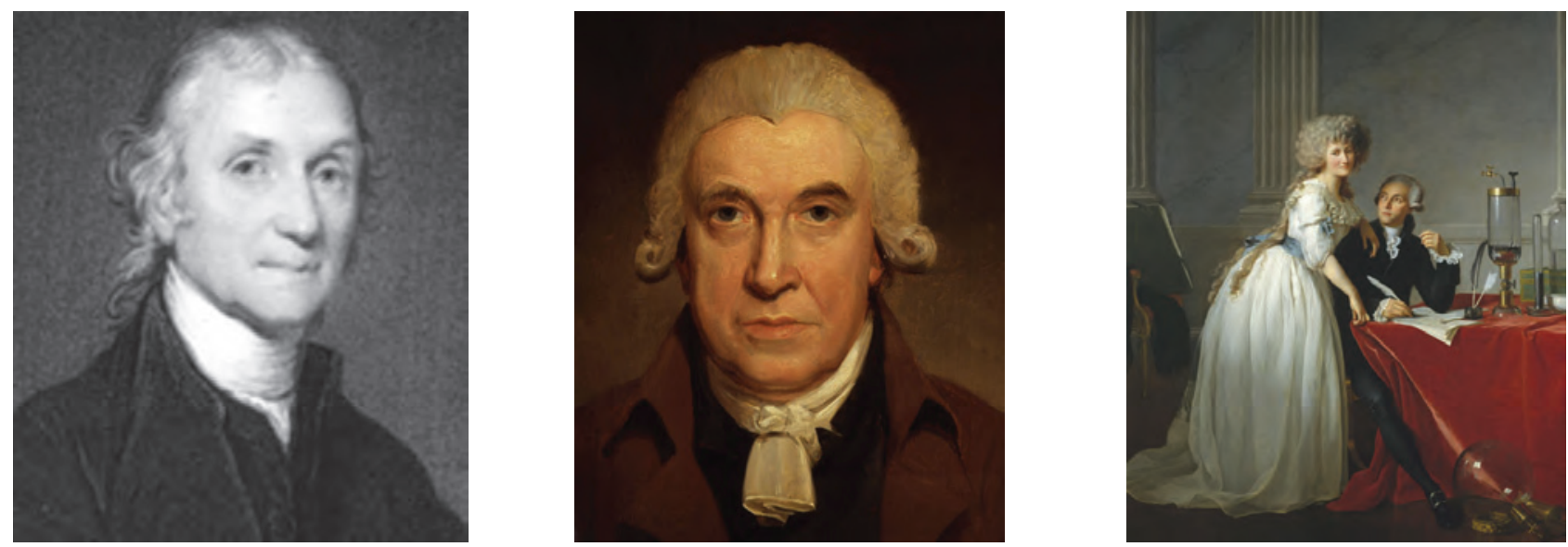

Figura 4 - Henry Cavendish (1731-1810), James Watt (1736-1819) e Antoine Lavoisier (1743-1794) 

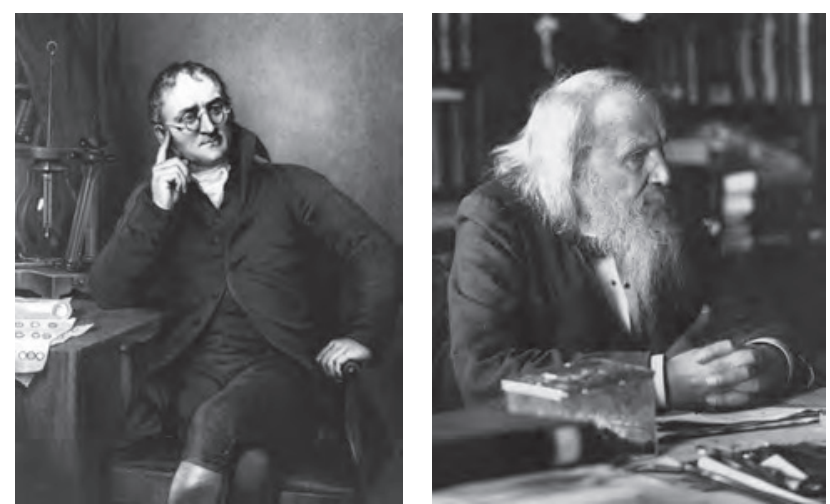

Figura 5 - John Dalton (1766-1844) e Dmitri Mendeleev (1834-1907)

Se, na sua universalidade e intemporalidade, as divindades mitológicas serviam o projeto d'O Anel, a tetrassomia alquímica, no seu classicismo, redutor mas decifrável, sobretudo numa leitura poética (para não dizer iniciática ou simbólica), ajustava-se na perfeição à edificação e descrição do cosmos da saga. Vejamos alguns aspetos d'O Anel do Nibelungo pelo prisma da alquimia.

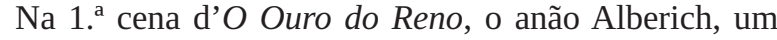
Nibelungo, tenta seduzir as Filhas do Reno (Figura 6) mas estas troçam da sua fealdade. Irrefletidamente, porém, informam-no de que o ouro de que são guardiãs encerra um grande dom: um anel feito a partir dele dará, a quem o possuir, poderes ilimitados, bastando para isso que renuncie ao amor. Está, assim, iniciada a saga do anel maldito que irá ser utilizado como paga de resgate, que será invejado, disputado e roubado, que fará matar pela sua posse e que finalmente voltará ao rio de onde nunca devera ter saído.

Quem são, afinal, as Filhas do Reno? Em boa verdade, não era n’O Ouro do Reno que criaturas desta natureza apareciam no palco musical pela primeira vez; nem seria a última. Recuando até 1681, a 'música de cena' composta por Marc-Antoine Charpentier para a comédia de Thomas Corneille e Jean Donneau de Vise La Pierre Philosophale inclui um coro para os quatro elementos primordiais e um dueto para o fogo e a água que prova que a força do

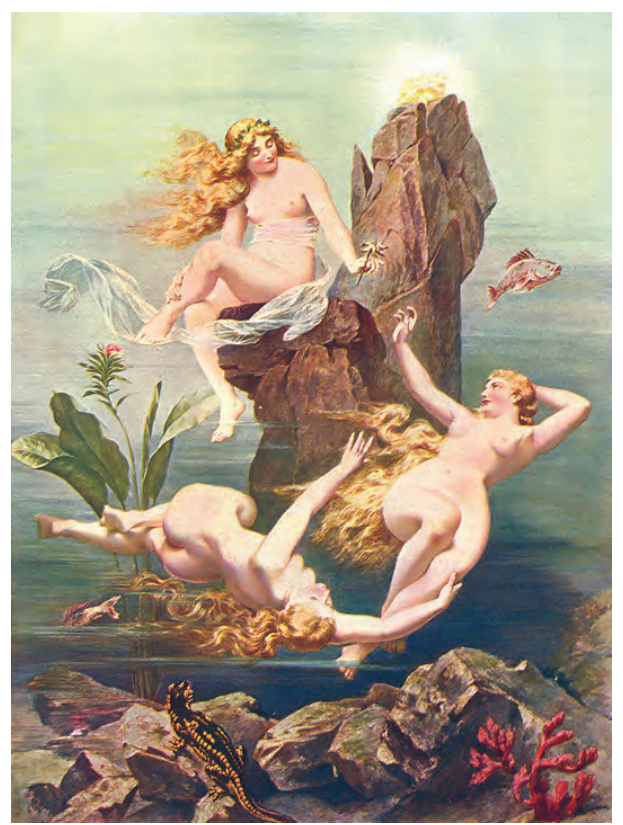

Figura 6 - As três Filhas do Reno d'O Anel do Nibelungo amor consegue aproximar os contrários (algo que também se verá no final d'O Anel!). A trama de La Pierre Philosophale inclui ainda os elementais, entidades que, de acordo com a alquimia paracelsiana, eram os espíritos da natureza associados a cada um dos quatro elementos: as ondinas (espíritos da água), os gnomos (espíritos da terra), as salamandras (espíritos do fogo) e os silfos (espíritos do ar). As Filhas do Reno são, assim, ondinas.

Voltando a O Ouro do Reno, na mudança para a 2. ${ }^{\text {a }}$ cena domina o ar: a água do rio evapora-se e ascende aos cumes das montanhas, formando nuvens que se dissipam em neblina. É nessas altitudes que se situa a monumental residência dos deuses, Valhalla, e é de lá que, na 3. ${ }^{\text {a }}$ cena, ao som de dezoito bigornas, Wotan, o deus supremo, e Loge, o deus do fogo, descem, através da fenda do enxofre, até ao Nibelheim. Aí, encontram-se os Nibelungos, que, escravizados por Alberich, forjam o ouro roubado do Reno. Os elementos dominantes são a terra e o fogo (este como força transformadora).

E quem é esse deus do fogo, Loge? Trata-se de uma divindade da mitologia nórdica, de acordo com a qual é igualmente o patrono dos ferreiros. É ardiloso e intriguista, mas representa a inteligência pura, sendo a ele que Wotan recorre sempre que está em apuros.

Na ópera $A$ Valquíria, após fazer adormecer a sua filha favorita, Brünnhilde - um sono mágico que é o castigo por ter ajudado Siegmund - Wotan invoca Loge para criar um fogo mágico que a rodeie e a proteja até ao dia em que um herói sem medo a acorde e a tome como esposa (Figura 7). (Esse herói será Siegfried, cujo nome dá o título à terceira ópera da Tetralogia.) A Valquíria termina com a "Música do Fogo Mágico”.

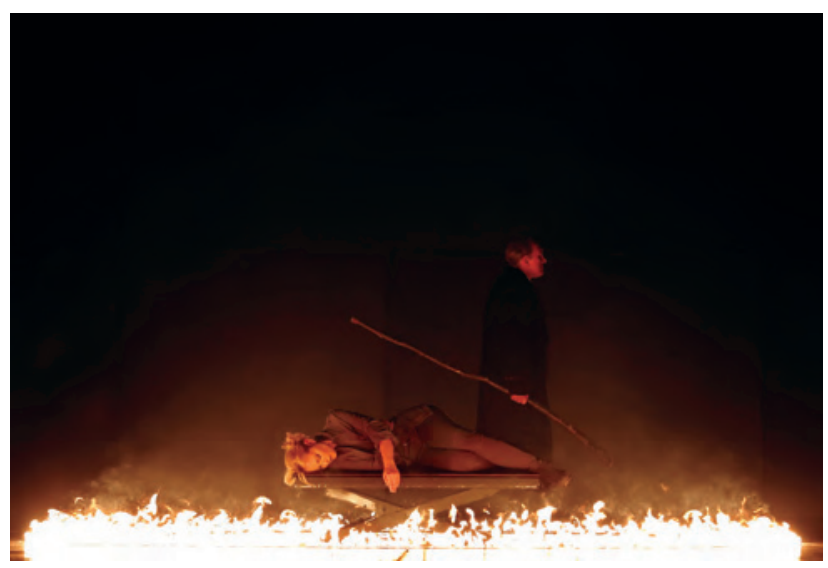

Figura 7 - Brünnhilde rodeada pelo fogo mágico (Opera Australia, Melbourne, 2016; foto: Jeff Busby)

Na quarta e última ópera da Tetralogia, Crepúsculo dos Deuses, será Brünnhilde que incendeia a pira funerária de Siegfried, imolando-se nela de seguida. É através deste fogo que se dá a consumação da união eterna dos dois amantes e a purificação do anel amaldiçoado, que regressa, por fim, ao Reno. O fogo alastra entretanto a Valhalla, fazendo a noite derradeira cair sobre os deuses.

\section{O metal maldito}

A crença aristotélica de todas as substâncias serem formadas por quatro elementos primordiais levou a que du- 
rante intermináveis séculos a disciplina alquímica fizesse o Homem acreditar que poderia terminar o que a Natureza não fizera, isto é, que podia operar a transmutação dos metais inferiores em ouro. Com efeito, durante muito tempo acreditou-se que os minérios surgiam na crosta terrestre após longos períodos de gestação no útero da Terra-mãe. Havia, por conseguinte, toda uma embriologia subterrânea que justificava que o Homem, quer como mineiro quer como ferreiro, atuasse como obstetra do reino mineral. Com as suas técnicas, ele conseguiria substituir-se ao tempo no processo de crescimento dos minérios e de formação dos metais. Destacava-se aqui o trabalho do ferreiro, que pela ação transformadora do fogo conseguia substituir-se ao tempo na formação dos metais, tudo levando a crer que, se aos materiais extraídos da Terra fosse dado tempo suficiente, estes se converteriam em metal puro. E, tivessem ainda mais uns milhares de anos, sem nenhuma perturbação exterior, se transmutariam em ouro. Esta crença subsistiu praticamente até às vésperas da Revolução Industrial.

Na Tetralogia de Wagner, a figura da Terra-mãe é representada por Erda, a deusa da Terra, que na 4. ${ }^{\text {a }}$ cena d'O Ouro do Reno surge imponentemente de uma fenda no solo, alertando Wotan para o desastre que a posse do anel acarretará. Ela voltará ao contacto com Wotan no III ato de Siegfried, levando-o a perceber que o fim da era daqueles deuses está iminente.

Acentue-se que as atividades mineira e metalúrgica foram essenciais para a Revolução Industrial, iniciada em Inglaterra no princípio do século XVIII, com o engenho atmosférico de Thomas Newcomen (1712), o qual, em 1765, pela mão de James Watt (Figura 4), seria melhorado com a introdução do condensador separado, dando um fôlego decisivo à revolução em curso. Com ela vieram, já no século XIX, os enormes fluxos migratórios do campo para os subúrbios das grandes cidades, geradores de uma nova classe social - ignorante, analfabeta, escravizada e a viver em condições miseráveis - sustentadora do recém-nascido sistema industrial-capitalista.

Por sua vez, os regimes autoritários nascidos no seio de uma Europa pós-napoleónica, envolvidos em lutas ferozes pelo domínio político e económico, deitaram por terra o grande sonho do Século das Luzes de uma reforma da sociedade com base em valores como liberdade, progresso, tolerância e fraternidade. Consequentemente, para um intelectual como Richard Wagner, guardião dos ideais Iluministas, o mundo tornara-se um local adverso e inabitável. Também fora ele, um militante de causas, que, imbuído de um forte nacionalismo germânico anti prussiano, participara em 1848 na revolta de Dresden (de que resultou a sua expulsão do território alemão e o exílio em Zurique) e que, no auge desse período revolucionário, chegou a afirmar que destruiria “a atual ordem das coisas!”. Efetivamente, Wagner mudou alguma coisa: na história da música há duas eras, antes e depois dele!

Nesta conjuntura político-económica não será de admirar a forte presença da arte de trabalhar os metais na sua Tetralogia. Para além da atividade metalúrgica dos Nibelungos escravizados, n'O Ouro do Reno destaca-se ainda a 3. ${ }^{\text {a }}$ cena do I ato de Siegfried (1876), na qual Mime, o anão ferreiro, irmão de Alberich, tenta em vão reparar a espada mágica Notung, destinada a matar o dragão Fafner, guardião do anel. Será, contudo, o jovem Siegfried (Figura 8) que a forjará de novo. ("Notung, Notung, espada de confiança! Acordei-te de novo para a vida”.)

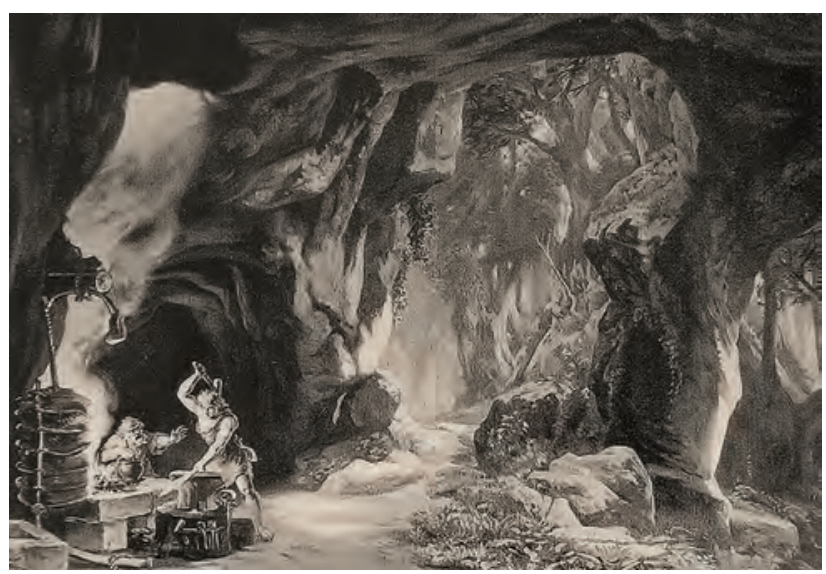

Figura 8 - Siegfried a forjar de novo a espada mágica Notung

Mas a metalurgia na produção artística de Richard Wagner não se ficou só por aí. Entre 1849 e 1850, baseando-se numa lenda nórdica, esboçou um libreto intitulado Wieland, o ferreiro, no qual é possível encontrar alguns elementos conhecidos de outras obras suas: um cisne, uma chaga, uma lança, um anel... E, recuando ainda mais no tempo, em 1842 tinha já delineado um libreto baseado no conto As Minas de Falun da autoria do grande escritor do romantismo alemão E.T.A. Hoffmann, publicado em 1819.

A ação deste conto, a todos os níveis fascinante, decorre no ambiente das célebres minas suecas (Figura 9), que o título evoca (outrora grandes fornecedoras de cobre da Europa e atualmente reconhecidas pela UNESCO como Património Mundial). Durante a narrativa de As Minas de Falun, Hoffmann faz-nos ir bem mais fundo do que ao interior da terra: penetramos nas profundezas da mente humana!

No caso d'O Ouro do Reno, o ouro surge faiscante sob a luz que atravessa as águas do rio, atraindo de imediato a cobiça de Alberich - o resto é já bem sabido! Ao longo d'O Anel, porém, fica patente que o ouro de per si é um metal perfeitamente inócuo, só adquirindo vilania ao ser manipulado - ponto de vista que, de resto, já não era novo. Na Eneida (29-19 a.C.), Virgílio mencionou a ganância por ele gerada: "O que não forças os peitos mortais, / sagrada fome do ouro!" (Livro III, versos 56-57). Plínio, o naturalista romano do primeiro século da era cristã, na sua Historia Natural referiu o efeito envenenador e corruptor do

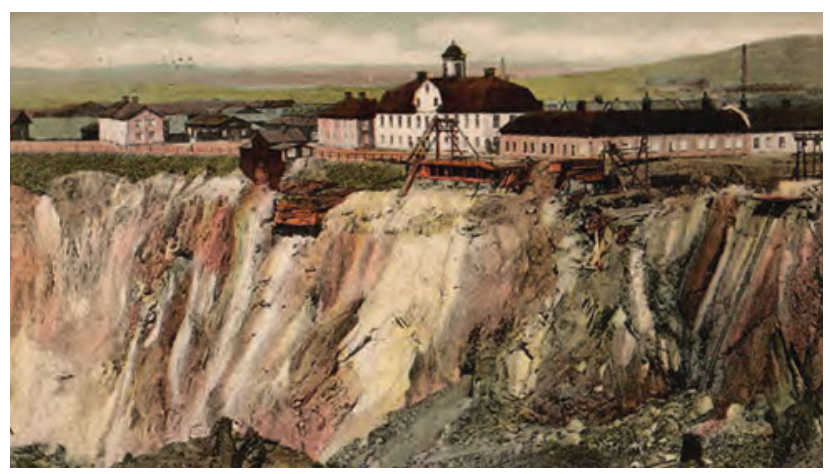

Figura 9 - Minas de Falun, Suécia (postal de 1907) 
metal amarelo, condenando tanto os que o usavam como os que o vendiam, chegando a desejar que "pudesse ser completamente banido da vida”. Segundo ele, depois de fundido, o ouro tornava-se um "símbolo de perversão e de exaltação dos desejos mais impuros”. Quinze séculos mais tarde, Georgius Agricola, o grande mineralogista alemão, considerado o pai da metalurgia moderna, partilhou dessa opinião e Thomas More, na sua Utopia (1516), chegou a dizer que o ouro não deveria ser usado para fazer adornos mas sim penicos. Por sua vez, William Shakespeare, em Timão de Atenas, chamou-lhe "mineral maldito" e "prostituta comum da humanidade que semeia a discórdia das nações".

No final d'O Ouro do Reno, repare-se no trocadilho dos lamentos das três ninfas aquáticas pela perda do ouro roubado: “Rheingold! Rheingold! Reines Gold!”. A chave do trocadilho está em 'rein', palavra que em alemão se pronuncia quase do mesmo modo que o nome do rio e que significa 'puro'.

Não deixa de ser curioso que $O$ Anel do Nibelungo, projeto que se arrastou ao longo de 26 anos, tenha tido início exatamente no ano em que começou a Gold Rush da Califórnia, ou seja, em 1848, acontecimento que serviria de base ao argumento de La fanciulla del West, de Giacomo Puccini. Nesta ópera, Nick, o barman do Polka, filosoficamente afirma que "o ouro envenena o sangue de quem o vislumbra”, que é o que rigorosamente acontece n'O Anel do Nibelungo, começando em Alberich e terminando em Hagen.

Para o deslumbramento que o ouro sempre exerceu sobre a humanidade - que terá até hoje extraído da Terra o equivalente a um cubo com vinte metros de aresta - contribuem não só a sua beleza intrínseca como, acima de tudo, a sua raridade. A título ilustrativo, a crosta terrestre é constituída por $5 \%$ de ferro (em termos de massa) mas somente por 0,0000005\% de ouro. (O metal mais abundante é o alumínio: 8\%.)

A ânsia pelo ouro foi sempre tão excessiva que o Homem chegou a ter o grande sonho alquímico de o obter a partir da transmutação de metais inferiores. Mas após longos e inglórios esforços acabaria por perceber que só lhe restava extraí-lo das entranhas da Terra, onde aparece na forma de filões incrustados em quartzo (ouro primário), ou, em alternativa, nas águas e areais dos rios para onde é arrastado sob a forma de partículas de dimensões variáveis, após processos de erosão dos filões originais (ouro secundário).

Richard Wagner estava certo: há mesmo ouro no Reno!

\section{Limites da ciência}

O Anel do Nibelungo, como vimos, surgiu como um cris de coeur de Wagner contra uma sociedade em mudança em que não se revia. Se em 1849 afirmara que "A ciência é o poder supremo do intelecto humano, mas a fruição desse poder é a arte”, em 1880, no seu ensaio Religião e Arte, já se mostrava apreensivo face à filosofia de utilitarismo com que era encarado o desenvolvimento científico da época, preocupando-o em particular que este pudesse ser posto ao serviço de interesses militares. Advertia que se o avanço científico não fosse contrabalançado com elevados princípios éticos e morais, ao invés do progresso traria con- sigo a degeneração da humanidade e, em última análise, a destruição da vida.

Na opinião de Wagner, o Homem iludia-se a si mesmo ao pensar que as descobertas científicas lhe permitiriam controlar a natureza; deveria, isso sim, acautelar-se porque esse suposto progresso levaria antes à criação de uma geração de humanos que pouco mais seriam do que máquinas.

Poderá neste julgamento reconhecer-se um certo olhar visionário do transumanismo - corrente intelectual que defende que os seres humanos por via tecnológica poderão um dia expandir enormemente as suas capacidades físicas, intelectuais e psicológicas - ideia que subjaz ao célebre romance futurístico de Aldous Huxley Admirável Mundo Novo, publicado em 1932. Algo que o economista e filósofo Francis Fukuyama também prevê, de forma mais pessimista, no livro de 2002 O Nosso Futuro Pós-Humano, Consequências da Revolução Biotecnológica.

Os supostos benefícios da Revolução Industrial eram também questionados pelo compositor, para quem existiam vários abusos em causa: desde a exploração mineira do carvão, que ele considerava ser um insulto à natureza, à dos próprios trabalhadores das minas. Era igualmente contra a destruição desenfreada do meio ambiente pelos caminhos-de-ferro, tendo, em 1880, expressado a sua opinião quanto à recém-criada linha transalpina de Gotthard (Figura 10).

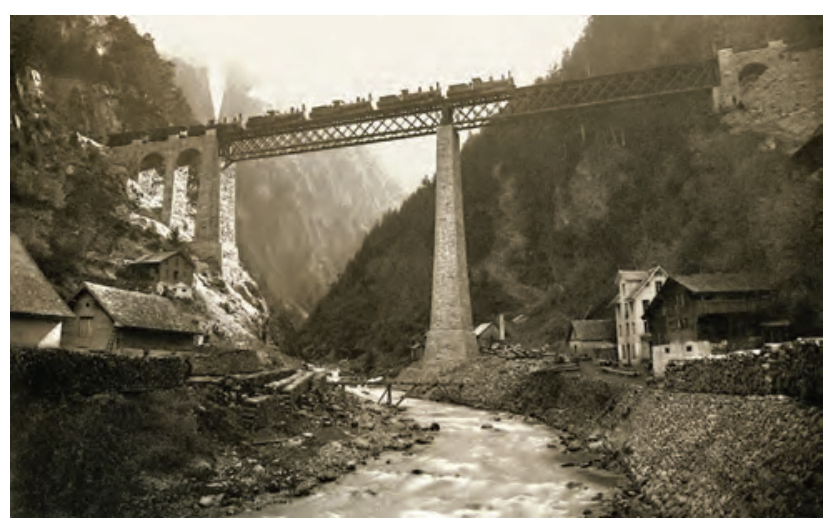

Figura 10 - Linha do Gotthard, Suíça (1880)

Para além disso, suspeitava que a eletricidade não tinha sido suficientemente testada e que era antinatural, e via com apreensão o fonógrafo, inventado por Thomas Edison em 1877 (Figura 11).

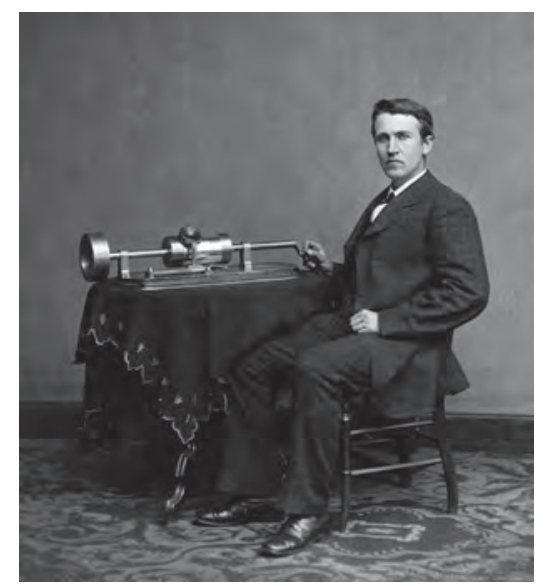

Figura 11 - Thomas Edison e o seu fonógrafo (1878) 
Os receios de Richard Wagner quanto aos perigos que poderiam decorrer do avanço científico não eram inéditos: já o próprio mentor do método científico, Francis Bacon, no início do século XVII, antevira tal possibilidade. A própria literatura encarregou-se ao longo dos tempos de alimentar os piores receios quanto aos aspetos perniciosos do desenvolvimento científico e industrial. Fausto - tanto o de Christopher Marlowe (1604) como o de Goethe (1808) -, Frankenstein (1818) de Mary Shelley e Tempos Difíceis (1854) de Charles Dickens, são obras onde a temática está patente e que Wagner poderia muito bem ter lido.

Para além dos receios quanto a uma mecanização do Homem, Wagner tinha outras preocupações de natureza bioética. Via todos os seres sensíveis como detentores de uma dimensão espiritual; a sua individualidade não era somente aquilo que a biologia dava a conhecer. Em 1879, a leitura de As Câmaras de Tortura da Ciência, um livro de Ernst von Weber que denunciava as experiências com animais em laboratórios médicos, comoveu-o profundamente. Essa sua preocupação com o sofrimento dos animais não era, contudo, nova: já a tinha expressado em 1858, numa carta a Mathilde Wesendonck (a mesma dos Wesendonck Lieder!), em que lhe descrevia a brutalidade do abate de aves nos matadouros.

A leitura do livro de von Weber motivou Wagner a escrever-lhe uma 'carta aberta', que publicou no Bayreuther Blätter. Nela, o compositor manifestava-se energicamente contra a dissecação de animais para fins científicos, tanto por questões práticas como éticas e filosóficas, argumentando que as experiências com animais nunca aliviavam o sofrimento do doente, muito menos forneciam uma cura. Como artista, dizia sentir-se desconfortável face ao comportamento incivilizado da sua "era desespiritualizada”, uma era caracterizada pelo "espectro da ciência [...] desde a bancada de dissecação à fábrica de armas de fogo”. Em lugar de uma ciência que unicamente obedecesse à razão e ao princípio do utilitarismo, advogava uma ciência feita com sentimento; só assim se chegaria ao verdadeiro conhecimento. A medicina experimental, envolvida numa mera recolha de dados fisiológicos, nunca esclareceria a causa do sofrimento infligido pela doença. Estudar em animais as doenças que lhes tinham sido artificialmente inoculadas era moralmente injusto; para não falar já das investigações efetuadas em doentes pobres hospitalizados. Acrescentava que só criando empatia com o doente, um médico poderia verdadeiramente saber do que este padecia. De resto, Wagner - no que teve algum pioneirismo - considerava que a doença era causada antes de mais por fatores socioculturais, e que só por mudança dos hábitos e das condições de vida é que seria erradicada.

Esta sua visão da relação do Homem com os animais, do médico com o paciente, das relações humanas em geral e mesmo do Homem com a Natureza - uma relação "tipificada pela ideia de companheiro de sofrimento" - levou autores como Joachim Thiery e Ulrich Tröhler, no The Wagner Compendium" ${ }^{1}$ a falarem de uma "cosmologia de compaixão” wagneriana.

\footnotetext{
X B. Millington (ed.), “The Wagner Compendium”, Thames \& Hudson, Londres, 1992
}

A propósito, refira-se que Wagner era contra a caça desportiva, tendo chegado a abraçar a causa do vegetarianismo (pelo menos no plano teórico), e toda a sua vida se rodeou de animais de estimação (Figura 12). Uma curiosidade: o seu cão favorito, Russ - um terra-nova - está enterrado aos pés do dono, no parque da Villa Wahnfried, em Bayreuth. Na lápide pode ler-se: “Aqui jaz e vigia o Russ de Wagner”.

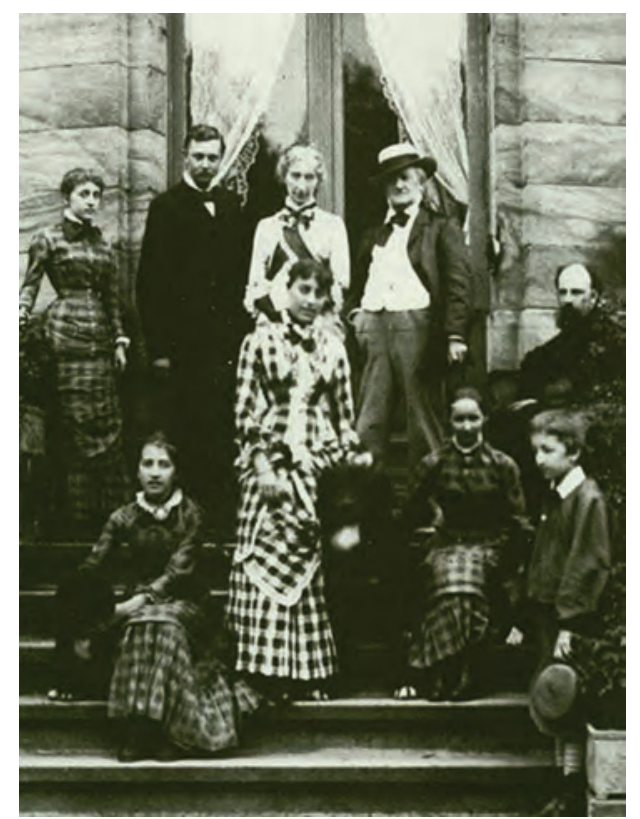

Figura 12 - A família Wagner e amigos na Villa Wahnfried; os dois cães são Marke e Russ (1881)

Parsifal, a última obra do compositor, conterá uma das cenas mais panfletárias da sua compaixão para com os animais: a morte do cisne por Parsifal, no I ato. Cheio de remorsos, este acaba por quebrar o arco com que disparara a seta fatal. No caso d'O Anel do Nibelungo, é também tocante quando na 2. ${ }^{\text {a }}$ cena do II ato de Siegfried, o jovem herói adquire a capacidade de entender a linguagem das aves, após ter levado à boca a mão manchada com o sangue do dragão Fafner (ex-gigante) que acabara de abater com a espada Notung. É justamente um pássaro da floresta que o aconselha a apoderar-se do anel e do elmo mágico; que o alerta para as pérfidas intenções de Mime (que o pretende envenenar) e que, finalmente, o guia até ao rochedo onde jaz a adormecida Brünnhilde, rodeada pelo fogo mágico.

\section{Melodia sem fim}

A Origem das Espécies, obra em que Charles Darwin apresentou a ideia de seleção natural como fator determinante da evolução dos animais, foi dada à estampa em Londres em 1859. Richard Wagner terminara a partitura de Tristão e Isolda havia cerca de três meses. Não consta que o naturalista inglês e o compositor alemão alguma vez se tenham encontrado ou sequer correspondido, ou mesmo que Darwin escutasse a música de Wagner, embora se saiba que este, alguns anos depois, leu A Origem das Espécies (numa altura em que ainda compunha $O$ Anel do Nibelungo). A escassez (para não dizer ausência) de troca de influências entre o cientista e o músico não obstou a que vários autores pudessem encontrar pontos de contacto nas conceções evolutivas patentes na obra de ambos. 
Perceberemos melhor alguns desses pontos de vista se atentarmos ao ensaio de Wagner de 1851, Ópera e Drama, no qual desferiu um violento ataque à artificialidade da ópera que se fazia em Itália e em França, bem como aos seus compositores (com Rossini e Meyerbeer, respetivamente, à cabeça). Segundo Wagner, para estes músicos “era como se a melodia não pertencesse ao reino da sua produção artística; era algo já pronto”. Às melodias “já feitas”, o compositor alemão contrapunha as melodias resultantes de um "desenvolvimento orgânico”. O exemplo que dava para ilustrar a sua exposição era o da música sinfónica de Beethoven, que ele dizia possuir "o impulso natural da vida”.

Nesse ensaio, Wagner acrescentava ainda que "Uma melodia já pronta [...] é-nos incompreensível por ser passível de interpretações arbitrárias”, chegando a comparar os seus dramas musicais à Natureza, ao dizer que esta “permaneceu indecifrável enquanto a olhámos como algo já concluído; agora que a encaramos como uma entidade cujo 'tornar-se' nos é dado continuamente a ver, ela revela-se suficientemente inteligível.” Todas estas referências de Wagner ao "desenvolvimento orgânico" da música revelam que no contexto do aceso debate que, em meados do século XIX, opunha o organicismo ao mecanicismo, o compositor seria partidário do primeiro, ou seja, da ideia de o todo ser mais do que a soma das suas partes.

Numa análise comparada de Tristão e Isolda e A Origem das Espécies, recentemente efetuada pelo compositor e professor universitário norueguês Edvin Østergaard², é salientado que a "ausência de progressões de efeitos harmónicos óbvios”, bem como o “contínuo adiar da resolução harmónica”, criam uma "sensação de continuidade, de inacabado, - e de incerteza”. O melhor exemplo disso é o famoso 'acorde de Tristão’.

O tratamento harmónico d'O Anel do Nibelungo não terá ido tão longe como em Tristão e Isolda, mas, tal como nessa obra, as melodias em constante progressão parecem estar por terminar, fazem continuamente parte de uma génese musical “orgânica”. Encontra-se aqui, aliás, mais um sinal da modernidade de Wagner, pioneiro do conceito de 'obra aberta', isto é uma obra destinada a ser apreendida e interpretada pelo espectador. N'O Anel ressalta sobretudo, tanto pela quantidade como pela recorrência, o uso de Leimotive - pequenos temas melódicos associados a personagens, lugares, situações e emoções que variam constantemente de registo e de instrumentação -, contribuindo para um fluxo de melodia que se encontra permanentemente em mudança. São cerca de duas centenas de Leimotive que podemos encontrar na Tetralogia - só 100 vezes menos que o número de genes do genoma humano!

Outro ponto em que é possível encontrar afinidades entre Wagner e Darwin é na ideia de desenvolvimento como um fluxo suave e contínuo ao longo do tempo. Em Ópera e Drama, o compositor afirmou que o novo drama deveria possuir a unidade da sinfonia - com a sua rede de temas transformados e modulados -, não devendo, por conseguinte, consistir numa sequência de árias isoladas, recitativos e ensembles. A tensão dramática não deveria nunca ser interrompida por solos virtuosísticos ou quaisquer outros elementos perturbadores. Em 1859 chegou a afirmar que "gostaria agora de chamar à minha mais delicada e profunda arte a arte da

${ }^{2}$ E. Østergaard, Journal of Aesthetic Education 45 (2011) 83-108 transição, dado todo o tecido da minha arte ser composto de tais transições: tudo o que é abrupto e súbito é-me agora repugnante.” Por sua vez, n’A Origem das Espécies, Darwin insistiu na ideia de que a mudança é gradual e contínua, sem saltos súbitos.

Cometa-se aqui, agora, a indiscrição de revelar algumas passagens do diário de Cosima Wagner que nos informam que o marido leu A Origem das Espécies. A 10 de Fevereiro de 1873, ela escreveu: "R. referiu que entre Schopenhauer e Darwin aconteceu a mesma coisa que entre Kant e Laplace: Schopenhauer teve a ideia e Darwin desenvolveu-a, talvez mesmo sem o conhecer, tal como Laplace seguramente não conheceu Kant”. Anos mais tarde, em 1881, Cosima voltou a referir-se aos comentários do marido acerca de Darwin e Schopenhauer: "O jornal traz um artigo, "Kant e Darwin”, tendo R. destacado a superioridade da interpretação do instinto feita por Schopenhauer, relativamente à de Darwin”.

Estes excertos do diário de Cosima são reveladores de vários aspetos: por um lado do interesse de Wagner por assuntos que não a música e o drama, e, por outro, da relação que ele estabelecia entre a filosofia de Arthur Schopenhauer e a Teoria da Evolução de Darwin, e, já agora, da enorme admiração que nutria pelo filósofo alemão, desde que em 1854 lera o seu O Mundo como Vontade e Representação.

A discussão da variação e da seleção como forças motrizes da evolução biológica segundo Darwin é frequentemente reduzida à ideia simplista da "sobrevivência dos mais aptos”, como se a evolução biológica fosse determinada por "genes egoístas” e por uma "natureza sanguinária”. Nada mais errado: Darwin foi um grande defensor da bondade, da compaixão e da simpatia como forças determinantes da evolução humana. No seu livro de 1871 A Descendência do Homem e Selecção em Relação ao Sexo (Figura 13) o naturalista refere que a expressão da simpatia “terá aumentado através da seleção natural, pois as comunidades que incluíam um maior número de elementos que demonstravam simpatia, floresciam mais e deixavam um maior número de descendentes."

Estudos recentes no domínio da biologia e psicologia das emoções têm confirmado como é grande a capacidade humana para a compaixão e a simpatia, constituindo-se possivelmente como a mais forte e natural das nossas tendências comportamentais. Isso nos diz o psicólogo norte-americano Dacher Keltner no seu livro Born to Be Good:

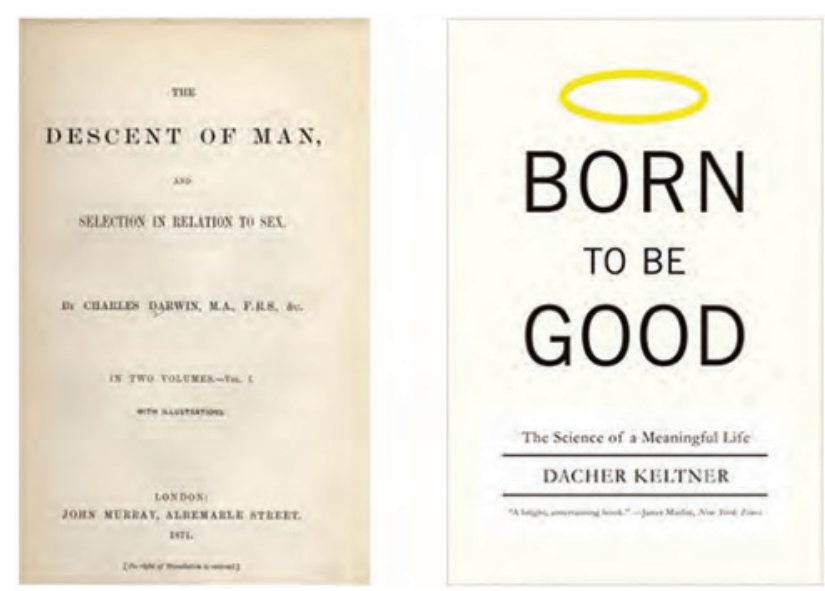

Figura 13 - A Descendência do Homem e Seleção em Relação ao Sexo (1871) de Charles Darwin, e Born to Be Good: The Science of a Meaningful Life (2009) de Dacher Keltner 
The Science of a Meaningful Life (Figura 13), publicado em 2009. Também não o tinha já dito John Lenonn em “All you need is love"?

Em suma, Wagner e Darwin, duas linguagens, uma mesma cosmologia: a da compaixão!

\section{CODA}

A arte, nas suas diversas manifestações, sempre traduziu a época de que emana. A ópera - tradicionalmente vista como um repositório de simples histórias de amor, ciúme, vingança, paixão e traição - não constitui exceção, revelando-se, em múltiplos casos, uma boa farejadora do 'espírito do tempo’, o Zeitgeist dos alemães. Nesse sentido, à época da sua criação, a Tetralogia $O$ Anel do Nibelungo de Richard Wagner - saga de deuses, anões e gigantes, e de um anel que conferia o poder de dominar o mundo a quem o possuísse - denunciava o sistema capitalista emergente da Revolução Industrial. A uma sociedade que vira na tecnologia a alvorada de melhores dias, mas cuja contrapartida se revelara demasiado impiedosa para tantos, a Tetralogia mostrava a precipitação da humanidade para o apocalipse, não deixando, todavia, de antever a possibilidade de uma nova era, de uma nova ordem, fundamentada na compaixão.

Não se pode afirmar, no entanto, que Wagner se opunha ao desenvolvimento científico ou à sua colocação à disposição do bem-estar da humanidade. Opunha-se, isso sim, à ciência guiada por interesses militares, a uma medicina desprovida de sentimento e à mecanização generalizada da sociedade.

O Anel do Nibelungo - apogeu da 'obra de arte total', a Gesamtkunstwerk que o autor preconizava - foi, assim, o seu grande manifesto contra o mundo do seu tempo. (Afinal, em jovem, já afirmara que destruiria a ordem das coisas!). De resto, o metafórico final de Crepúsculo dos Deuses (Figura 14) revelou não ser desprovido de fundamento: 31 anos após a sua morte eclodiu a I Guerra Mundial.

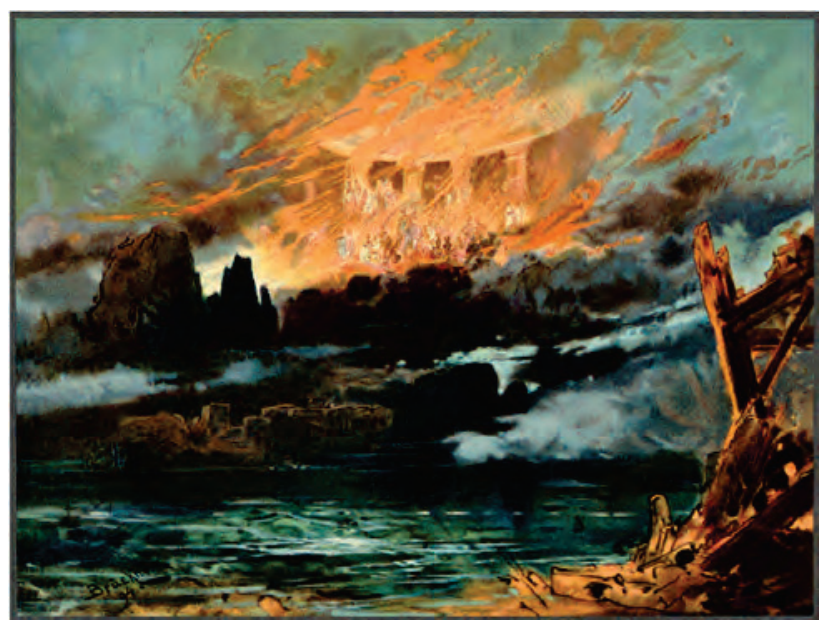

Figura 14 - Valhalla em chamas (cenário de Max Brückner para a cena final de Crepúsculo dos Deuses, levado à cena em Bayreuth em 1896)

Convoco, para encerrar, um personagem d'O Anel: o pássaro da floresta - recorrendo a um poema de Rainer Maria Rilke dirigido a um rouxinol e escrito cerca de um ano antes da I Guerra Mundial.

Sou eu, rouxinol, eu, quem tu cantas, Aqui, no meu coração, a violência dessa voz Já não se pode evitá-la

(tradução de Vasco Graça Moura)

\section{Agradecimentos}

Ao Círculo Richard Wagner pelo convite para a palestra que esteve na base deste artigo; ao João Paulo Rapagão pela leitura crítica do texto e pelo apoio na preparação da apresentação; ao revisor do manuscrito pelas valiosas correções e sugestões que o melhoraram.

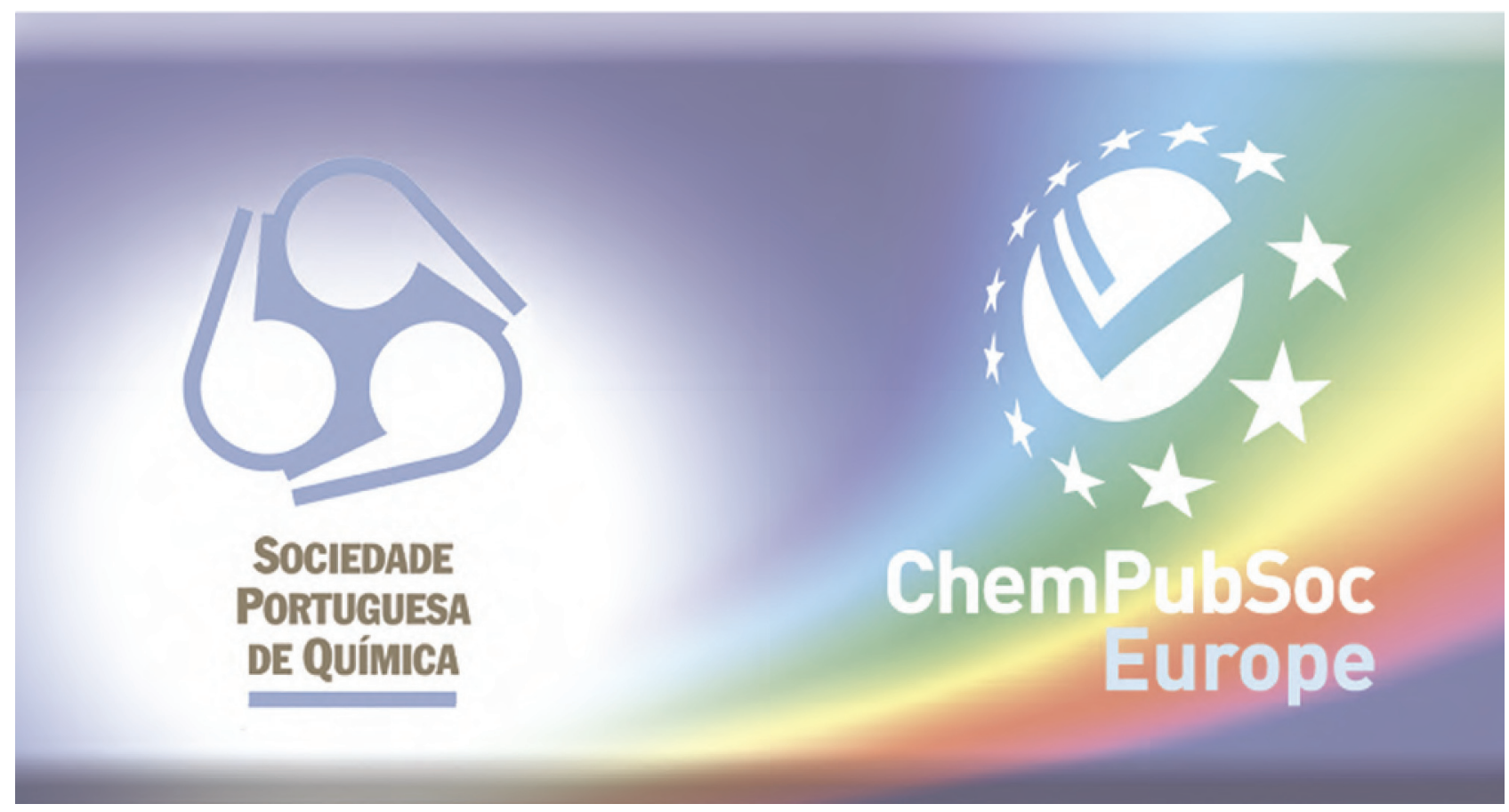

